Article

\title{
Preparation and Characterization of $\alpha$-Zinc Molybdate Catalyst: Efficient Sorbent for Methylene Blue and Reduction of 3-Nitrophenol
}

\author{
Hicham Oudghiri-Hassani ${ }^{1,2, *}$, Souad Rakass ${ }^{1}$, Mostafa Abboudi ${ }^{1}$, Ahmed Mohmoud ${ }^{1}$ \\ and Fahd Al Wadaani ${ }^{1}$ \\ 1 Chemistry Department, College of Science, Taibah University, Al-Madinah 30002, Saudi Arabia; \\ rakass_souad@yahoo.fr (S.R.); abboudi14@hotmail.com (M.A.); caadil77@yahoo.co.uk (A.M.); \\ fwadaani@taibahu.edu.sa (F.A.W.) \\ 2 Département Sciences de la Nature, Cégep de Drummondville, 960 rue Saint-Georges, \\ Drummondville, QC J2C 6A2, Canada \\ * Correspondence: oudghiri_hassani_hicham@yahoo.com; Tel.: +966-54-3549454
}

Received: 14 May 2018; Accepted: 15 June 2018; Published: 15 June 2018

\begin{abstract}
Zinc molybdate $\left(\mathrm{ZnMoO}_{4}\right)$ was prepared by thermal decomposition of an oxalate complex under a controlled temperature of $500{ }^{\circ} \mathrm{C}$. Analyses of the oxalate complex were carried out using Fourier transform infrared spectroscopy (FTIR) and thermogravimetric analysis (TGA). On the other hand, analyses of the synthesized zinc molybdate were carried out by X-ray diffraction (XRD), transmission electron microscopy (TEM), and Brunauer-Emmett-Teller technique (BET). The efficiency of the synthesized catalyst was tested with the reduction reaction of 3-nitrophenol (3-NP), and was also applied as a sorbent for methylene blue dye (MB) in aqueous solutions. The catalytic test of zinc molybdate shows a very high activity. The concentration reduction progress and adsorption of the dye were followed by an ultraviolet-visible (UV-vis) spectrophotometer.
\end{abstract}

Keywords: zinc molybdate; nitrophenol reduction; sorbent; methylene blue; nanoparticles

\section{Introduction}

Zinc molybdate is among the most studied ternary oxides in the family $\mathrm{AMoO}_{4}(\mathrm{~A}$ is a transition element or a divalent metal from the alkaline earth column). It exists in two crystallographic varieties, the $\alpha-\mathrm{ZnMoO}_{4}$, which has a triclinic cell where the zinc is in an octahedral site and the molybdenum is in a tetrahedral site, and the $\beta-\mathrm{ZnMoO}_{4}$, that is monoclinic with both of zinc and molybdenum in octahedral geometry. $\mathrm{ZnMoO}_{4}$ is not soluble in water, which reduces its toxicity. It is used as a white pigment [1]. This material was used in a variety of applications, such as photocatalysis [2-5], as phosphor for light emitting diode [6-13], electrochemical anode material for lithium batteries [14], in scintillating bolometers for double beta decay of ${ }^{100} \mathrm{Mo}$ [15,16], humidity sensors [17], antibacterial [18], biological imaging of deep tumors [19], supercapacitor [20], and as catalyst in the oxidation of propane and propene [21,22]. Traditionally, the zinc molybdate varieties are prepared by a conventional solid-state reaction [8,12], hydrothermal or solvothermal [2,5,7,10,11,19,20], mechanochemical [23], combustion synthesis [24], co-precipitation [3,19,25], sol-gel [26], or sonochemical method [6]. To our knowledge, there is no investigation reported on the use of zinc molybdate as catalyst in the reduction of nitrophenol to aminophenol, and neither in dye removal from polluted industrial waters. The reduction of the nitro group to the amine group is an important step in the synthesis of chemicals and drugs. For example, the reduction of the para-nitrophenol produces the para-aminophenol, which is used in the synthesis of the paracetamol (acetaminophen) drug [27]. On the other hand, water remediation is a concern of researchers across the world. Many efforts are made in order to replace the use of the activated carbon by materials 
having the same or better efficiency in dye removal by adsorption from polluted industrial waters and using low-cost materials. For this purpose, materials from natural products were largely investigated, such as agricultural wastes [28-30] or clay minerals [31-33]. Research on de-colorization was also focused, for example, on the use of metals oxides [34,35] or composite materials [36-38].

Therefore, in this contribution, we report the synthesis of the $\alpha-\mathrm{ZnMoO}_{4}$ nanomaterial using a different method that uses precursors, such as oxalate complexes of zinc and molybdenum. The prepared $\alpha-\mathrm{ZnMoO}_{4}$ nanoparticles were investigated for two applications: for their catalytic efficiency in the reduction of the 3-nitrophenol (3-NP) to the 3-aminophenol (3-AP), and for their efficiency in dye removal from polluted waters. The methylene blue was taken as a standard dye.

\section{Experimental}

\subsection{Preparation of Zinc Molybdate}

Zinc molybdate was prepared by first grinding together oxalic acid $\mathrm{H}_{2} \mathrm{C}_{2} \mathrm{O}_{4} \cdot 2 \mathrm{H}_{2} \mathrm{O}$, ammonium molybdate $\left(\mathrm{NH}_{4}\right)_{6} \mathrm{Mo}_{7} \mathrm{O}_{24} \cdot 4 \mathrm{H}_{2} \mathrm{O}$, and zinc nitrate $\mathrm{Zn}\left(\mathrm{NO}_{3}\right)_{2} \cdot 6 \mathrm{H}_{2} \mathrm{O}$ at a ratio of 10/0.143/1 [39]. This mixture produced an oxalate precursor at a temperature of $160^{\circ} \mathrm{C}$. All the chemical reagents were of analytical grade, purchased from Sigma-Aldrich, and were used in their received state.

Reduction of nitrate and molybdenum anions was carried out with an excess of oxalic acid (Equation (1)), in order to form a coordinated complex of zinc and molybdenum. The complex formation and redox reactions were established by heating, in their solid state, on a hot plate. When nitrate anion $\left(\mathrm{NO}_{3}{ }^{-}\right)$and molybdenum VI were reduced at a temperature of $160{ }^{\circ} \mathrm{C}$ (Equations (2) and (3)), a brown-orange evolving gas and pale-blue powder were observed. This was due to the formation of $\mathrm{NO}_{2}$ gas (Equation (4)) and zinc molybdenum complex, respectively. Finally, the zinc molybdenum complex was thermally decomposed in order to form the zinc molybdate by heating in static air under a temperature of $500{ }^{\circ} \mathrm{C}$ inside a tubular furnace opened at both ends [40-43].

$$
\begin{gathered}
\mathrm{C}_{2} \mathrm{O}_{4}{ }^{2-} \rightarrow 2 \mathrm{CO}_{2}+2 \mathrm{e}^{-} \\
\mathrm{Mo}^{\mathrm{VI}} \text { (white) }+2 \mathrm{e}^{-} \rightarrow \mathrm{Mo}^{\mathrm{IV}} \text { (blue) } \\
\mathrm{NO}_{3}{ }^{-}+4 \mathrm{H}^{+}+3 \mathrm{e}^{-} \rightarrow \mathrm{NO}+2 \mathrm{H}_{2} \mathrm{O} \\
\mathrm{NO}+\frac{1}{2} \mathrm{O}_{2} \rightarrow \mathrm{NO}_{2} \text { (brown-orange) }
\end{gathered}
$$

\subsection{Analysis and Characterization of Zinc Molybdate}

Thermal analysis of the prepared zinc molybdenum complex was carried out by thermogravimetric analysis (TGA, SQT 600, Ta Instruments, New Castle, DE, USA). Characterization was established using FTIR (Shimadzu 8400S, Tokyo, Japan) in the range of 400-4000 $\mathrm{cm}^{-1}$, preparing the sample as a $\mathrm{KBr}$ pellet. Adsorption-desorption isotherms and particle sizes were measured using Micromeritics ASAP 2020 surface area and porosity analyzer (Micromeritics, Norcross, GA, USA), with the equation $\mathrm{D}_{\mathrm{BET}}=6000 / \mathrm{d}$.S, where $\mathrm{d}$ is the density, and $\mathrm{S}$ is the specific surface area. The crystalline nanoparticles, in the range of $10^{\circ}$ to $80^{\circ}$ in $2 \theta$ of the sample, were identified by X-ray diffractometer 6000 (Shimadzu, Tokyo, Japan) installed with $\lambda_{\mathrm{Cu}-\mathrm{K} \alpha}=1.5406 \AA$ Á and Ni filter. The spherical particle size was worked out using the Scherer equation $D_{X R D}=0.9 \lambda /(B \cos \theta)$, where $B$ is the full width at half maximum (FWHM) expressed in radians, $\lambda$ is the $\mathrm{Cu}-\mathrm{K} \alpha$ wavelength, and $\theta$ is the Bragg angle. During the adsorption of methylene blue dye and the reduction reaction of 3-nitrophenol (3-NP), the solution concentration was measured using Varian Cary 100 spectrophotometer (Varian Inc, Palo Alto, CA, USA), and the shape and particle size were calculated using JEM-1400 electron microscope (JOEL, Peabody, MA, USA). 


\subsection{3-Nitrophenol Reduction Test}

The catalytic activity of zinc molybdate was tested with the reduction of 3-NP. The test solution included an aqueous solution mixture consisting of $40 \mathrm{~mL}$ of $4 \times 10^{-4} \mathrm{M}$ 3-NP with $40 \mathrm{~mL}$ of $8 \times 10^{-4} \mathrm{M}$ sodium tetrahydroborate $\left(\mathrm{NaBH}_{4}\right)$, stirring steadily at room temperature. The presence of nitrophenolate ion was observed by the visual appearance of a dark yellow color and an absorption peak at $393 \mathrm{~nm}$ for the 3-NP. The effect of the zinc molybdate catalyst was investigated with the UV-vis spectrophotometer when $0.1 \mathrm{~g}$ of the catalyst was added to the solution mixture, which resulted in the disappearance of the dark yellow color.

\subsection{Adsorption Test}

Solutions of different concentrations of methylene blue dye for the adsorption test were prepared from a stock solution of $1000 \mathrm{mg} \cdot \mathrm{L}^{-1}$. Adsorption of methylene blue by zinc molybdate nanoparticles was conducted by adding $0.1 \mathrm{~g}$ of the $\mathrm{ZnMoO}_{4}$ into $100 \mathrm{~mL}$ of methylene blue solution. The $\mathrm{pH}$ of the solution was adjusted before the addition, to $\mathrm{pH}=3$. Solutions were filtered by Thermo Scientific Syringe Filters in $4 \mathrm{~mm}, 17 \mathrm{~mm}$, and $30 \mathrm{~mm}$ diameters with pore size of $0.2 \mu \mathrm{m}$. The residual methylene blue concentration was analyzed with UV-vis spectrophotometer at $\lambda_{\max }=665 \mathrm{~nm}$. The removed percentage (\%) of methylene blue and the amount adsorbed at equilibrium $\left(\mathrm{q}_{\mathrm{e}}\right)$ were calculated with the following equations accordingly:

$$
\begin{gathered}
\text { Removal \% }=\frac{\mathrm{C}_{0}-\mathrm{C}_{\mathrm{e}}}{\mathrm{C}_{0}} \times 100 \\
\mathrm{q}_{\mathrm{e}}=\frac{\left(\mathrm{C}_{0}-\mathrm{C}_{\mathrm{e}}\right)}{\mathrm{W}} \times \mathrm{V}
\end{gathered}
$$

where $\mathrm{q}_{\mathrm{e}}\left(\mathrm{mg} \cdot \mathrm{g}^{-1}\right)$ is the amount of the MB dye adsorbed at equilibrium by the synthesized zinc molybdate nanoparticle, $\mathrm{C}_{0}$ is the initial dye concentration $\left(\mathrm{mg} \cdot \mathrm{L}^{-1}\right), \mathrm{C}_{\mathrm{e}}$ is the dye concentration at equilibrium $\left(\mathrm{mg} \cdot \mathrm{L}^{-1}\right) ; \mathrm{W}$ is the mass of the adsorbent $(\mathrm{g})$, and $\mathrm{V}$ is the volume of the solution ( $\mathrm{L}$ ).

\subsection{Desorption Test}

The desorption of MB was studied on a sample obtained from the adsorption in the case of the aqueous solution of $130 \mathrm{ppm}$ of $\mathrm{MB}$ at $\mathrm{pH}=5$, to get an idea about the recycling possibility and the reuse of the catalyst. The experiment was done by putting $0.1 \mathrm{~g}$ of the filtered catalyst in $100 \mathrm{~mL}$ of a solution of ethanol/water (50/50) maintained under stirring at room temperature. The variation of the concentration of the desorbed MB in the solution was followed by UV visible spectrophotometer. The desorption rate was calculated by the following equation:

$$
\text { Desorption } \%=\frac{\mathrm{C}_{d e s}}{\mathrm{C}_{a d s}} \times 100
$$

where $\mathrm{C}_{\text {des }}$ is the amount of the MB dye desorbed by the solution of ethanol/water (50/50), and $\mathrm{C}_{a d s}$ is the amount of the MB dye adsorbed in the case of the aqueous solution of $130 \mathrm{ppm}$ of $\mathrm{MB}$ at $\mathrm{pH}=5$.

\section{Results and Discussion}

\subsection{Complex Identfication and Characterization}

The product of the reaction in the solid state mixture of oxalic acid, zinc nitrate, and ammonium molybdate, which was ground and calcinated at $160{ }^{\circ} \mathrm{C}$, showed the functional groups identified by FTIR spectroscopy.

A variety of wide bands can be seen from the IR spectrum in Figure 1 . The constituents of these bands show that assignments at $1734 \mathrm{~cm}^{-1}$ and $1678 \mathrm{~cm}^{-1}$ are given to the $\mathrm{C}=\mathrm{O}$ vibration of the oxalate 
group [44]. This is in agreement with the C-O stretch [44] at $1403 \mathrm{~cm}^{-1}$. On the other hand, the bands at 1322 and $1367 \mathrm{~cm}^{-1}$ are distinctive to $\delta(\mathrm{OCO})$ and $v(\mathrm{C}-\mathrm{O})$, respectively [45].

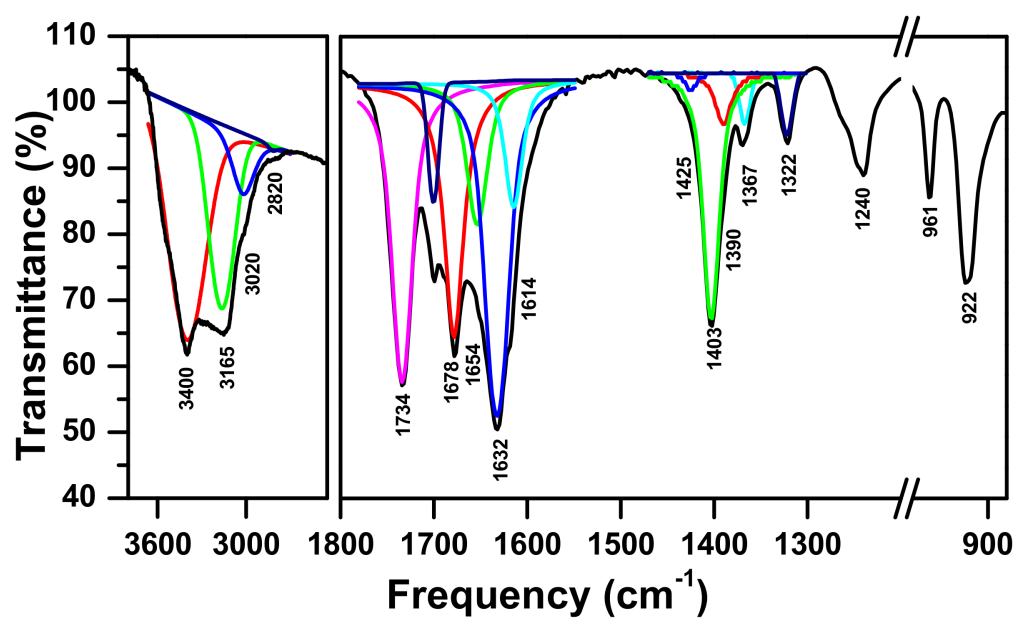

Figure 1. The FTIR spectrum for the mixture of oxalic acid $\mathrm{H}_{2} \mathrm{C}_{2} \mathrm{O}_{4} \cdot 2 \mathrm{H}_{2} \mathrm{O}$ at $160{ }^{\circ} \mathrm{C}$, ammonium molybdate $\left(\mathrm{NH}_{4}\right)_{6} \mathrm{Mo}_{7} \mathrm{O}_{24} \cdot 4 \mathrm{H}_{2} \mathrm{O}$, and nickel nitrate $\mathrm{Zn}\left(\mathrm{NO}_{3}\right)_{2} \cdot 6 \mathrm{H}_{2} \mathrm{O}$.

Ammonia and ammonium ion are both present via the deformation modes of the asymmetric and symmetric bands at $1614 \mathrm{~cm}^{-1} \delta_{\mathrm{s}}\left(\mathrm{NH}_{3}\right), 1240 \mathrm{~cm}^{-1} \delta_{\mathrm{as}}\left(\mathrm{NH}_{3}\right)$, and at $1654 \mathrm{~cm}^{-1} \delta_{\mathrm{s}}\left(\mathrm{NH}_{4}^{+}\right), 1425 \mathrm{~cm}^{-1}$ $\delta_{\text {as }}\left(\mathrm{NH}_{4}{ }^{+}\right)$, respectively. It can also be seen that the bands at $3020 \mathrm{~cm}^{-1}$ and $2820 \mathrm{~cm}^{-1}$, and at $3165 \mathrm{~cm}^{-1}$ in the NH stretching region, are identified as the ammonium ions and coordinated ammonia, respectively. The findings of the study agree with Ramis et al. [46] and Wen et al. [47]. There are two metals with a bridging group of $\mathrm{O}-\mathrm{H}$, which can be seen at $3400 \mathrm{~cm}^{-1}[48,49]$. The absorbance spectrum for the $\delta(\mathrm{OH})$ is shown at $1390 \mathrm{~cm}^{-1}$ [49], whereas the band at $1632 \mathrm{~cm}^{-1}$ is assigned to $\delta\left(\mathrm{H}_{2} \mathrm{O}\right)[50]$. Furthermore, the bands at $961 \mathrm{~cm}^{-1}$ and $922 \mathrm{~cm}^{-1}$ distinguish the presence of the $\mathrm{Mo}=\mathrm{O}$ stretch [44]. Therefore, it can be confirmed that the synthesized complex contains functional groups such as water, $\mathrm{NH}_{3}$, oxalate, $\mathrm{NH}_{4}$ ion, hydroxyl $(-\mathrm{OH})$, and oxo $(\mathrm{Mo}=\mathrm{O})$.

Studies of the thermogravimetric analysis (Figure 2) were carried out on the synthesized complex under static air. The obtained curve shows the distinction of three parts. The decline of the curve up to $170{ }^{\circ} \mathrm{C}$ is due to the weight loss of $4.6 \%$, which can be explained as the loss of water molecules in the synthesized complex, and this agrees with the confirmation of the reported infrared spectroscopy. The remaining parts of the curve show a fast loss from $170^{\circ} \mathrm{C}$ to $440^{\circ} \mathrm{C}$, this is due to the decomposition of the synthesized complex with a weight loss of $42.15 \%$. After careful studies, collection of the results from TGA and FTIR, with the oxidation degree of molybdenum and zinc, the suggested formula can be concluded as $\left(\mathrm{NH}_{3}\right)\left(\mathrm{NH}_{4}\right) \mathrm{ZnMoO}\left(\mathrm{C}_{2} \mathrm{O}_{4}\right)_{2}(\mathrm{OH}) \cdot \mathrm{H}_{2} \mathrm{O}$. The theoretical figure of $46.75 \%$ is in agreement with the suggested formula with a total weight loss of $46.75 \%$. The zinc molybdate complex was obtained via calcination at a carefully chosen constant temperature of $500{ }^{\circ} \mathrm{C}$. 


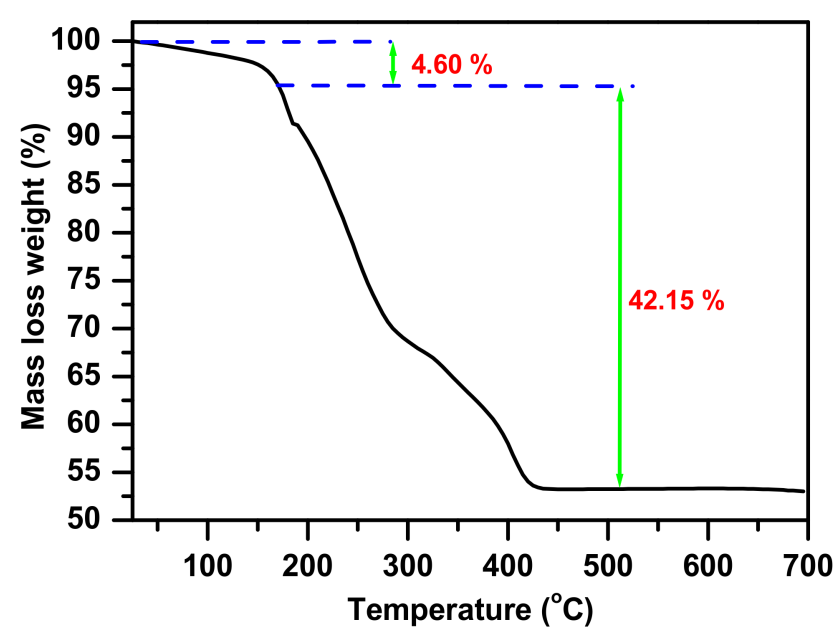

Figure 2. Thermogravimetric curve for the complex consisting of an oxalic acid $\mathrm{H}_{2} \mathrm{C}_{2} \mathrm{O}_{4} \cdot 2 \mathrm{H}_{2} \mathrm{O}$, ammonium molybdate $\left(\mathrm{NH}_{4}\right)_{6} \mathrm{Mo}_{7} \mathrm{O}_{24} \cdot 4 \mathrm{H}_{2} \mathrm{O}$, and zinc nitrate $\mathrm{Zn}\left(\mathrm{NO}_{3}\right)_{2} \cdot 6 \mathrm{H}_{2} \mathrm{O}$ at a temperature of $160{ }^{\circ} \mathrm{C}$.

\subsection{Zinc Molybdate Characterization}

\subsubsection{X-ray Diffraction}

The X-ray diffraction (XRD) technique was used to analyze the end-produced complex after calcination at $500{ }^{\circ} \mathrm{C}$, and the presented pattern shown in Figure 3 was recorded. The XRD pattern agrees with the JCPDS \#35-0765 index file. This matches with the triclinic phase $\alpha-Z n M o O_{4}$ that crystallizes in the space group $\mathrm{P} \overline{1}(2)$ with parameters $\mathrm{a}=8.3678(8), \mathrm{b}=9.6916(8)$, and $\mathrm{c}=6.9643(6)$, and $\alpha=106.872(8), \beta=101.726(8)$, and $\gamma=96.734(8)$.

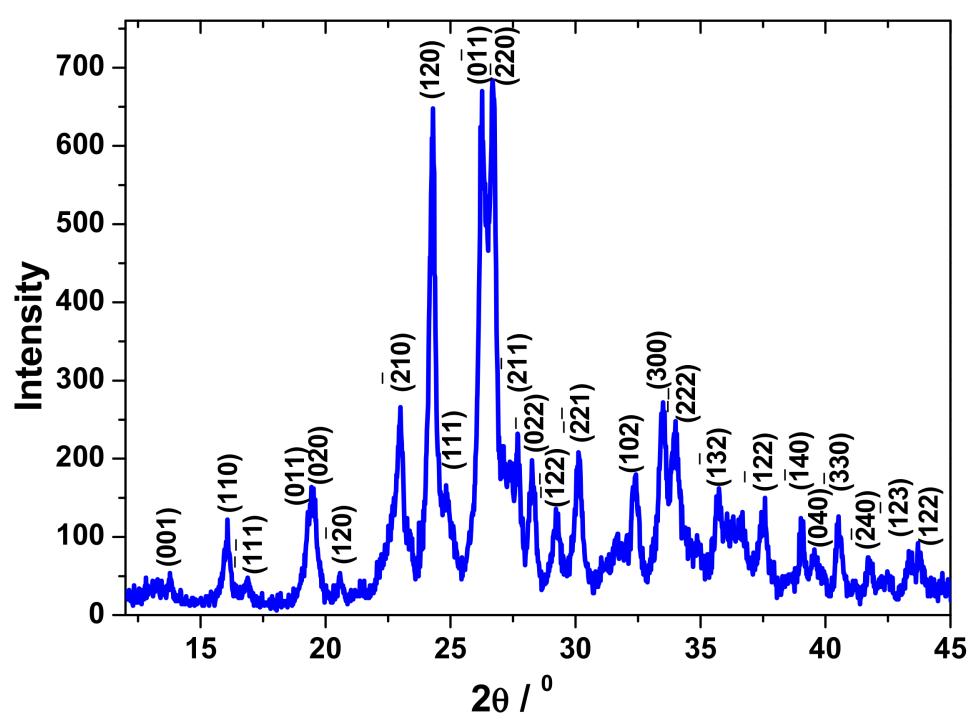

Figure 3. X-ray diffraction pattern of the synthesized zinc molybdate after calcination the oxalate complex at a temperature of $500{ }^{\circ} \mathrm{C}$.

The highest $d$ spacing which was chosen to calculate the crystallite size, and $\mathrm{D}_{\mathrm{XRD}}$ was the intense peak located at $2 \theta=24.18^{\circ}(120)$, and this gives a value for $D_{X R D}$ to be of $24 \mathrm{~nm}$.

\subsubsection{Specific Surface Area Determination}

Brunauer-Emmett-Teller (BET) method [51] was used to find out the specific surface area of the synthesized zinc molybdate, $\mathrm{ZnMoO}_{4}$. With the density value of the zinc molybdate being 
$\mathrm{d}=4.3 \mathrm{~g} / \mathrm{cm}^{3}$, it was found out that the $\mathrm{S}_{\mathrm{BET}}=18.9 \mathrm{~m}^{2} / \mathrm{g}$, and the particle size $\mathrm{D}_{\mathrm{BET}}$ was calculated to be approximately of $74 \mathrm{~nm}$. Barrett, Joyner, and Halenda (BJH) method calculations allows us to find out that the pore volume was $0.1428 \mathrm{~cm}^{3} / \mathrm{g}$ with a pore size of $297 \AA$. This indicates that the material has mesoporous characteristics [52].

\subsubsection{Transmission Electron Microscopy}

Figure 4 shows a synthesized zinc molybdate micrograph. The particles are between 70 to $100 \mathrm{~nm}$ in size, and are in a spherical shape. The particle size observed from BET, $74 \mathrm{~nm}$, is in accordance with that found in transmission electron microscopy (TEM), 70-100 nm. However, the X-ray diffraction analysis does not confirm the same value. The value, $24 \mathrm{~nm}$, observed in the XRD analysis where the crystallite size is reached, is different from particle size. When the particles agglomerate, they form particles of greater size, lowering the adsorption rate of the liquid nitrogen molecules. The resulting specific surface area value will decrease, giving higher particle sizes than expected. On the other hand, the crystallite size is measured in $\mathrm{XRD}$, even if the powder is agglomerated into larger particles, because the crystallites are separately crystallized.

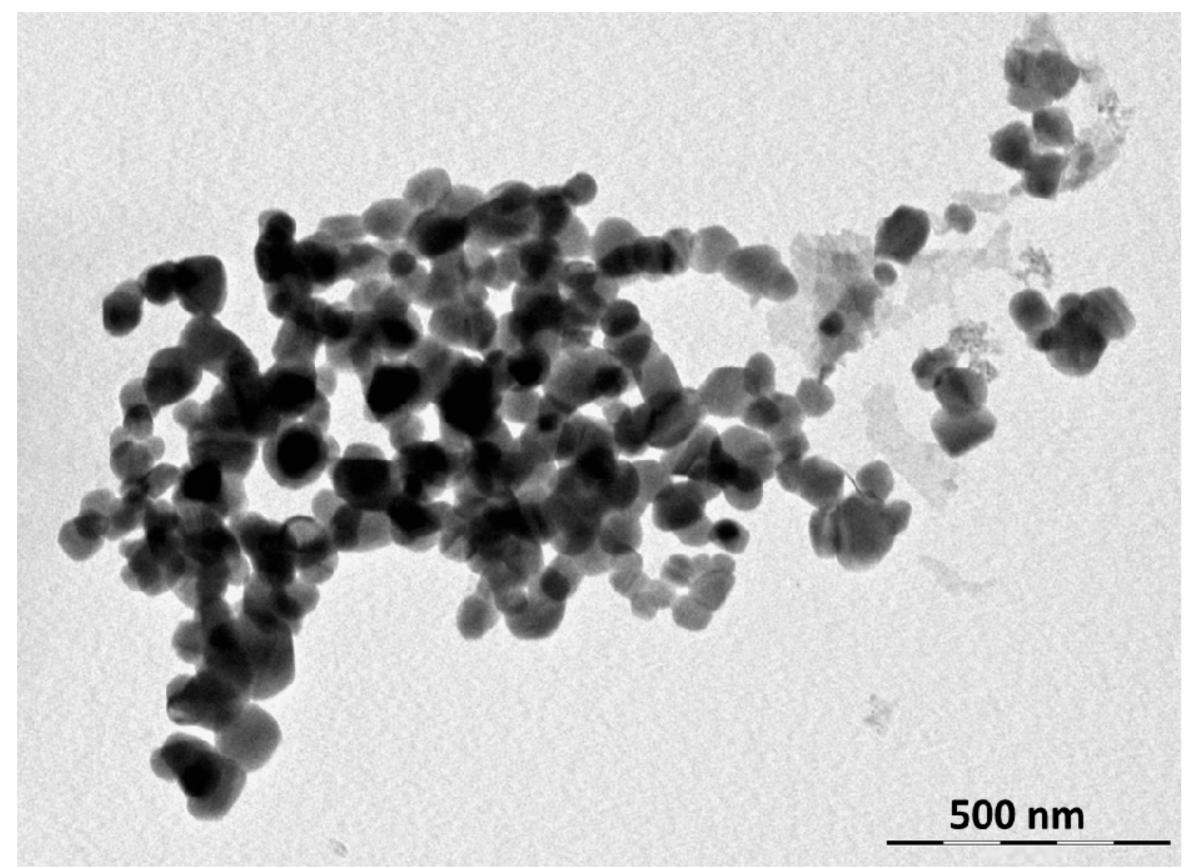

Figure 4. Micrograph of the transmission electron microscopy for the synthesized zinc molybdate, $\mathrm{ZnMoO}_{4}$, gained after calcination of the oxalate complex at a temperature of $500{ }^{\circ} \mathrm{C}$.

\subsection{3-Nitrophenol Reduction Test}

The synthesized zinc molybdate was tested to investigate the catalytic efficiency for the reduction reaction of 3-nitrophenol, 3-NP, against $\mathrm{NaBH}_{4}$ (Figure 5). After the addition of $\mathrm{NaBH}_{4}$, the 3-NP converted to 3-NP ion nitrophenolate. The dark yellow color of the 3-NP solution disappears in few minutes after the addition of the zinc molybdate nanocatalyst, whilst for the addition of the as-prepared catalyst alone, the color of the solution did not change, even for a period of over $24 \mathrm{~h}$. The UV-vis absorption peak comparison shows that the higher peak of absorption situated at $393 \mathrm{~nm}$ disappears in favor to a new peak appearing at $328 \mathrm{~nm}$. The observed time taken for the complete reaction with the appearance of the corresponding 3-aminophenol (3-AP), at room temperature, was around $1 \mathrm{~min}$. The results confirmed the high catalytic efficiency of the synthesized zinc molybdate in the reduction of 3-nitrophenol compared to previously reported research work in the literature, as shown in Table 1. 

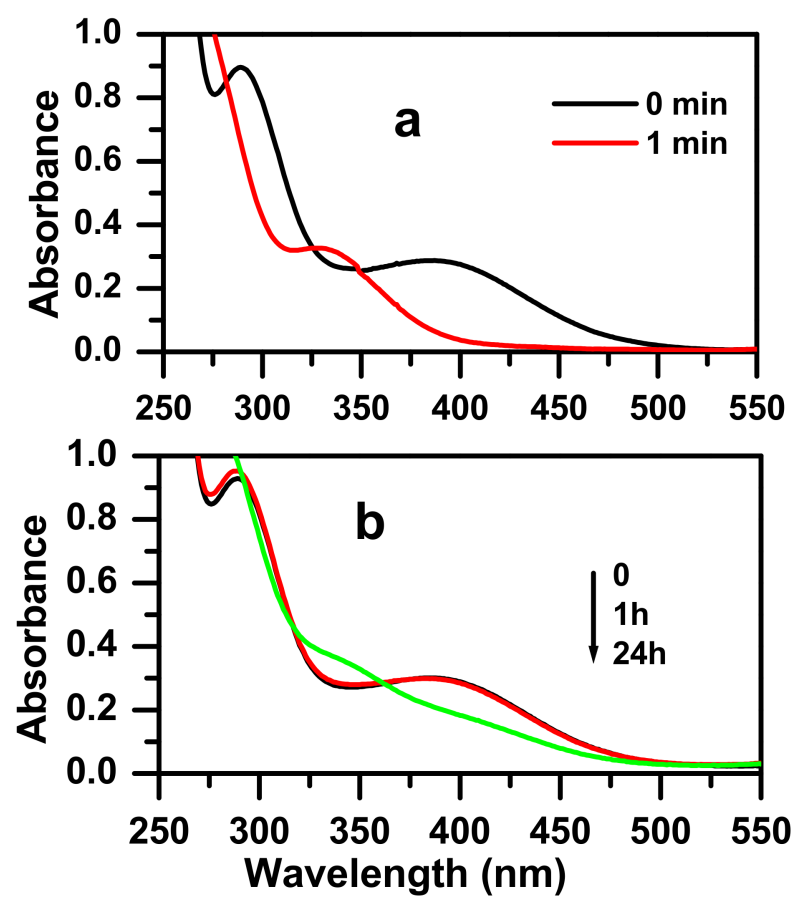

Figure 5. The UV-visible spectra for the reduction reaction solution of 3-NP in the presence of $\mathrm{NaBH}_{4}$ at room temperature (a) after the addition of zinc molybdate, $\mathrm{ZnMoO}_{4}$, prepared by calcination of the oxalate complex at a temperature of $500{ }^{\circ} \mathrm{C}$, and (b) without adding the catalyst.

Table 1. Reaction time comparison for the reduction of 3-NP by $\mathrm{ZnMoO}_{4}$ with previously reported nanocatalysts.

\begin{tabular}{ccccc}
\hline Catalyst & Type & $\begin{array}{c}\text { Concentration of } \\
\text { NP (mol/L) }\end{array}$ & $\begin{array}{c}\text { Reaction Time } \\
\text { (min) }\end{array}$ & References \\
\hline $\mathrm{ZnMoO}_{4}$ & Nanoparticles & $2 \times 10^{-4}$ & 1 for 3-NP & This work \\
$\mathrm{Fe}_{2}\left(\mathrm{MoO}_{4}\right)_{3}$ & Nanoparticles & $2 \times 10^{-4}$ & 6 for 3-NP & {$[39]$} \\
$\mathrm{CuFe}_{2} \mathrm{O}_{4}$ & Nanoparticles & $3.6 \times 10^{-5}$ & 5 for 3-NP & {$[53]$} \\
$\mathrm{NiFe}_{2} \mathrm{O}_{4}$ & Nanoparticles & $3.6 \times 10^{-5}$ & 36 for 3-NP & {$[53]$} \\
$\mathrm{NiMoO}_{4}$ & Nanoparticles & $2 \times 10^{-4}$ & 3 for 3-NP & {$[54]$} \\
$\mathrm{CuO} / \gamma \mathrm{Al}_{2} \mathrm{O}_{3}$ & Nanocomposites & $2.9 \times 10^{-5}$ & 20 for 3-NP & {$[55]$} \\
$\mathrm{CoMoO}$ & Nanoparticles & $2 \times 10^{-4}$ & 1 for 3-NP & {$[56]$} \\
$\mathrm{Ni} / \mathrm{C}$ black & Nanocomposites & $5.0 \times 10^{-4}$ & 15 for 3-NP & {$[57]$} \\
\hline
\end{tabular}

However, catalytic reduction tests done on the para-nitrophenol (4-NP) and the ortho-nitrophenol (2-NP) show a very low efficiency of our catalyst, as the reduction reaction takes more than $48 \mathrm{~h}$. The catalytic reduction was possible only for the 3-NP. This can be due to the difference between the three isomers where the 3-NP is being more basic ( $\mathrm{pKa}=8.3$ ), due to the conjugation across the ring where the negative charge appears in ortho and para positions. For the 2-NP and 4-NP isomers, the negative charge appears only at the meta position ( $\mathrm{pKa}=7.3$ and 7.2 respectively) (Figure 6). 


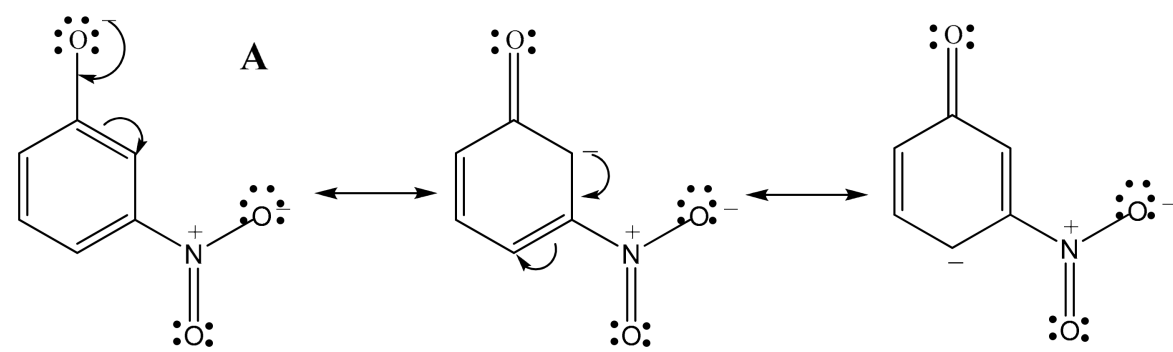<smiles>N#Cc1ccccc1[N+](=O)[O-]</smiles>

B

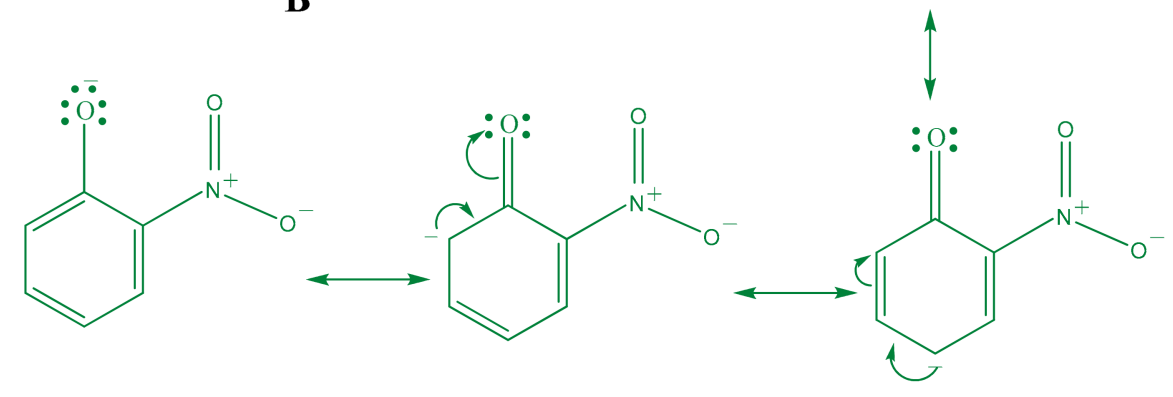<smiles></smiles><smiles>O=c1ccc([N+](=O)[O-])cs1</smiles><smiles>O=[N+]([O-])C1C=CC(=[W])C=C1</smiles>

C<smiles></smiles><smiles>O=C1C=CC(=O)C([N+](=O)[O-])=C1</smiles><smiles>[3H][3H]</smiles>
(C) is 4-NP.

On the other hand, in the case of the 3-NP, the electrons of the nitro group did not contribute in the conjugation, which makes them available, and makes the nitro group more reactive. A mechanism can 
be hypothetically suggested for the reduction of the 3-nitrophenol by $\mathrm{NaBH}_{4}$ in the presence of zinc molybdate catalyst. A mechanism with three reduction steps needing six electrons and dehydration steps is indicated in Figure 7.

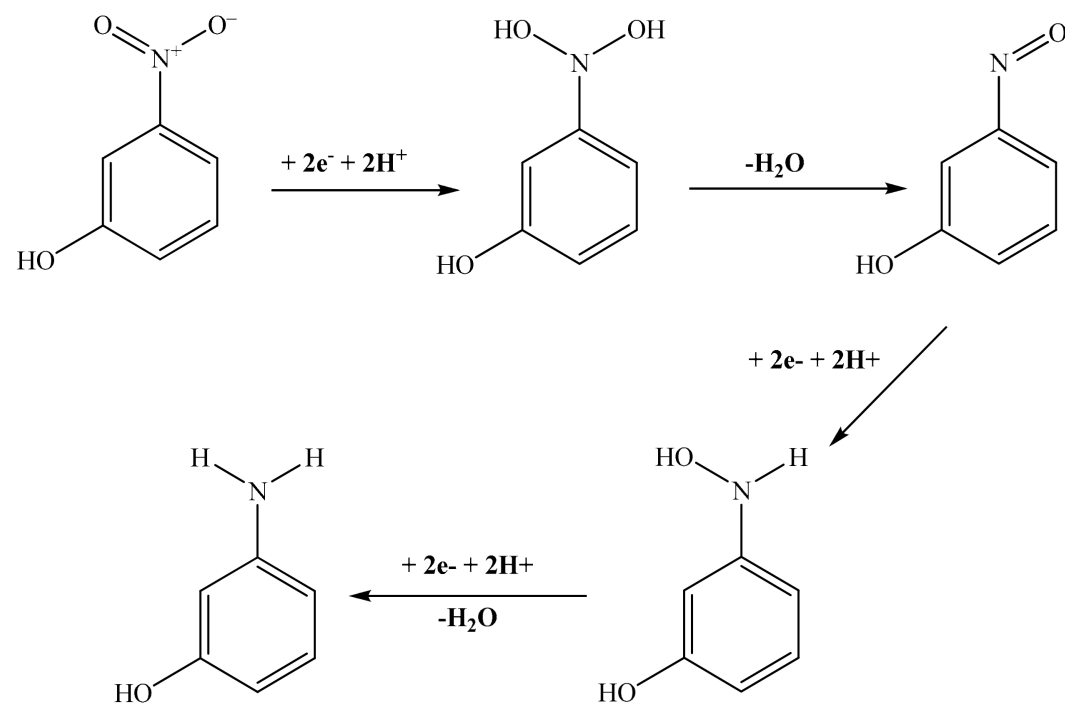

Figure 7. Proposed reduction mechanism of the 3-NP to 3-AP by $\mathrm{NaBH}_{4}$ in the presence of the prepared zinc molybdate.

This mechanism is based on the adsorption of the reducing agent that will be dissociated, liberating electrons that will reduce the adsorbed nitrophenol molecules. In fact, the zinc molybdate nanoparticles (ZnMoNPs) dissociated the $\mathrm{BH}_{4}{ }^{-}$to form $\mathrm{ZnMoNPs}-\mathrm{H}$ and $\mathrm{ZnMoNPs}-\mathrm{BH}_{3}{ }^{-}$as reactive intermediates (Equation (8)) [58]. Afterward, the 3-nitrophenol will be reduced as indicated in (Equations (9) and (10)).

$$
\begin{aligned}
& 2 \mathrm{ZnMoNPs}+\mathrm{BH}_{4}{ }^{-} \leftrightarrow \text { ZnMoNPs-H }+\mathrm{ZnMoNPs}^{-\mathrm{BH}_{3}}{ }^{-} \\
& 6 \mathrm{ZnMoNPs}-\mathrm{H}+3-\mathrm{NP} \rightarrow 3-\mathrm{AP}+6 \mathrm{ZnMoNPs}+2 \mathrm{H}_{2} \mathrm{O}
\end{aligned}
$$

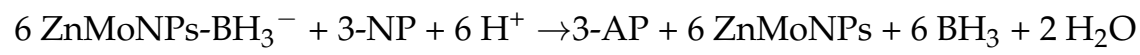

\subsection{Zinc Molybdate as Sorbent for Methylene Blue Removal}

\subsubsection{Effect of Initial Dye Concentration}

The adsorption of cationic dye molecules is affected significantly by its $\mathrm{pH}$, which is an important factor. The experiments were carried out in the $\mathrm{pH}$ range of 3-11, and the results show that the best condition for high removal of methylene blue $(\mathrm{MB})$ is at $\mathrm{pH}=3$ (Figure 8 ). This result suggests an important role of the acidic media. Based on this, a mechanism can be proposed where, in the first step, protonation of the MB gives positively charged ammonium entities $\left(-\mathrm{N}^{+}\right)$. In the second step, an electrostatic interaction occurs between these ammonium entities and the oxygen atoms of the zinc molybdate catalyst, that permits the adsorption of MB on the catalyst surface (Figure 9). 

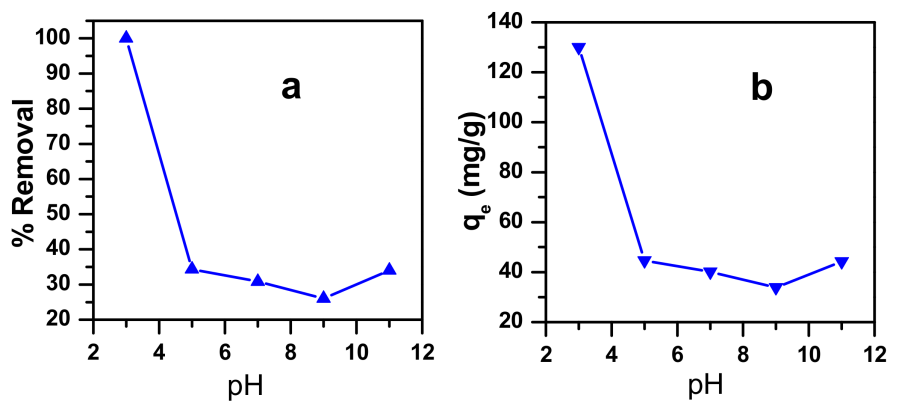

Figure 8. Effect of $\mathrm{pH}$ on $\mathrm{MB}$ dye adsorption onto zinc molybdate (a) removal efficiency (b) adsorption capacity at equilibrium.

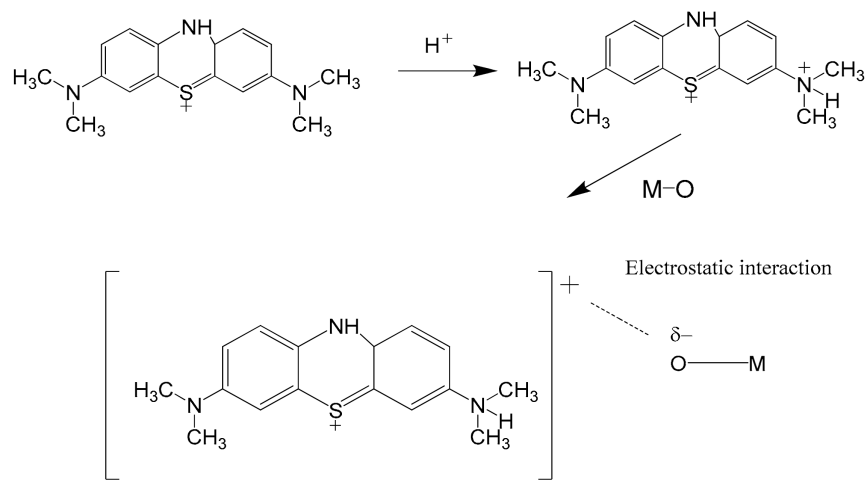

Figure 9. Schematic mechanism of the MB adsorption on the zinc molybdate nanoparticles surface.

The relationship between the dye concentration and the active sites available on the adsorbent surface affects the initial dye concentration. In fact, the effect of contact time adsorption of MB from an aqueous phase onto zinc molybdate surface was investigated at different contact time intervals in the range of 0 to $120 \mathrm{~min}$. The results in Figure 10 show that the removal of $\mathrm{MB}$ by zinc molybdate reaches a maximum value of $100 \%$ at about $10 \mathrm{~min}$, with a concentration range of $130 \mathrm{ppm}$ to $200 \mathrm{ppm}$. However, at a concentration higher than $200 \mathrm{ppm}$, the percentage removal, after $120 \mathrm{~min}$, reached $87 \%$ for $250 \mathrm{ppm}$. On the other hand, the results obtained for the adsorption capacity at equilibrium increases from $130 \mathrm{mg} / \mathrm{g}$ to $218 \mathrm{mg} / \mathrm{g}$, with an increase in the initial dye concentration from $130 \mathrm{mg} / \mathrm{L}$ to $250 \mathrm{mg} / \mathrm{L}$. Once the sites of the surface adsorbent were totally filled with MB dye molecules, there were no more surface adsorbent sites available for binding, and hence, the maximum adsorption was reached at this point [59].
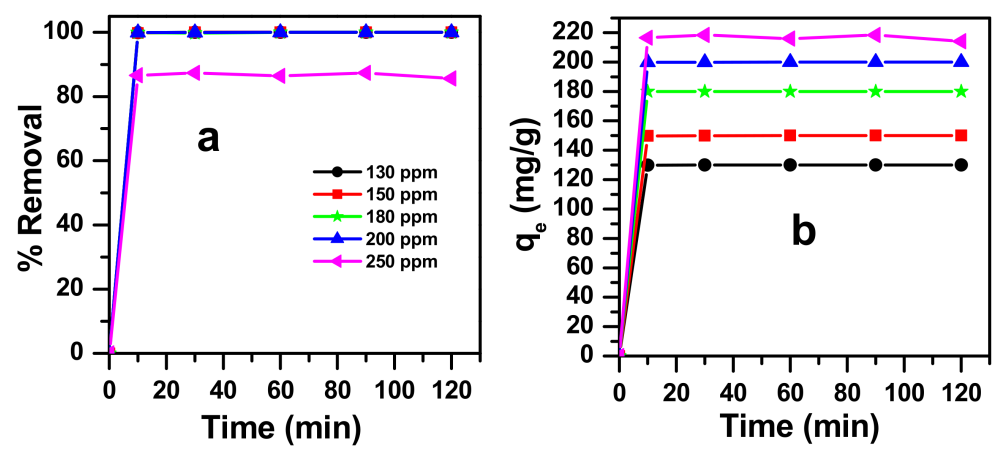

Figure 10. Effect of contact time on $\mathrm{MB}$ dye adsorption onto zinc molybdate at $\mathrm{pH}=3$ (a) removal efficiency (b) adsorption capacity at equilibrium. 


\subsubsection{Adsorption Isotherm}

The adsorption data are analyzed by proper adsorption isotherm models test. Freundlich and Langmuir isotherms are applied to the gained data of MB adsorption onto zinc molybdate. The Langmuir isotherm explains the adsorption of adsorbate on homogeneous adsorbent, as well as the monolayer adsorption, where there are no interactions between the adsorbate molecules. The Langmuir model linear equation is represented as follows [60]:

$$
\frac{\mathrm{C}_{\mathrm{e}}}{\mathrm{q}_{\mathrm{e}}}=\frac{1}{\mathrm{q}_{\mathrm{m}} \mathrm{K}_{\mathrm{L}}}+\frac{\mathrm{C}_{\mathrm{e}}}{\mathrm{q}_{\mathrm{m}}}
$$

where $K_{L}\left(\mathrm{~L} \cdot \mathrm{mg}^{-1}\right)$ is the Langmuir constant, which is related to the energy of the adsorption, and $\mathrm{q}_{\mathrm{m}}$ $\left(\mathrm{mg} \cdot \mathrm{g}^{-1}\right)$ is the maximum amount sorbed when the monolayer is complete.

The following equation defines the dimensionless constant, $\mathrm{R}_{\mathrm{L}}$ :

$$
\mathrm{R}_{\mathrm{L}}=\frac{1}{1+\mathrm{K}_{\mathrm{L}} \mathrm{C}_{\mathrm{i}}}
$$

where $C_{i}$ is the initial dye concentration $\left(\mathrm{mg} \cdot \mathrm{L}^{-1}\right)$ and $\mathrm{K}_{\mathrm{L}}$ is the Langmuir constant. The $\mathrm{R}_{\mathrm{L}}$ value shows that the Langmuir isotherm is linear $\left(R_{L}=1\right)$, irreversible $\left(R_{L}=0\right)$, favorable $\left(0<R_{L}<1\right)$, and unfavorable $\left(R_{L}>1\right)$ [53]. Adsorption of adsorbate on a heterogeneous adsorbent is best described in the Freundlich isotherm model. The Freundlich linear model equation is shown as follows [61]:

$$
\mathrm{Lnq}_{\mathrm{e}}=\mathrm{Lnq}_{\mathrm{F}}+\frac{1}{\mathrm{n}} \mathrm{LnC}_{\mathrm{e}}
$$

where $\mathrm{n}$ and $\mathrm{q}_{\mathrm{F}}$ are isotherm constants which indicate the intensity of the adsorption and adsorption capacity, respectively.

The Freundlich and Langmuir adsorption isotherms of zinc molybdate nanoparticles for the removal of MB dye molecules are shown in Figure 11. The adsorption parameters of Freundlich and Langmuir for zinc molybdate are calculated and listed in Table 2.
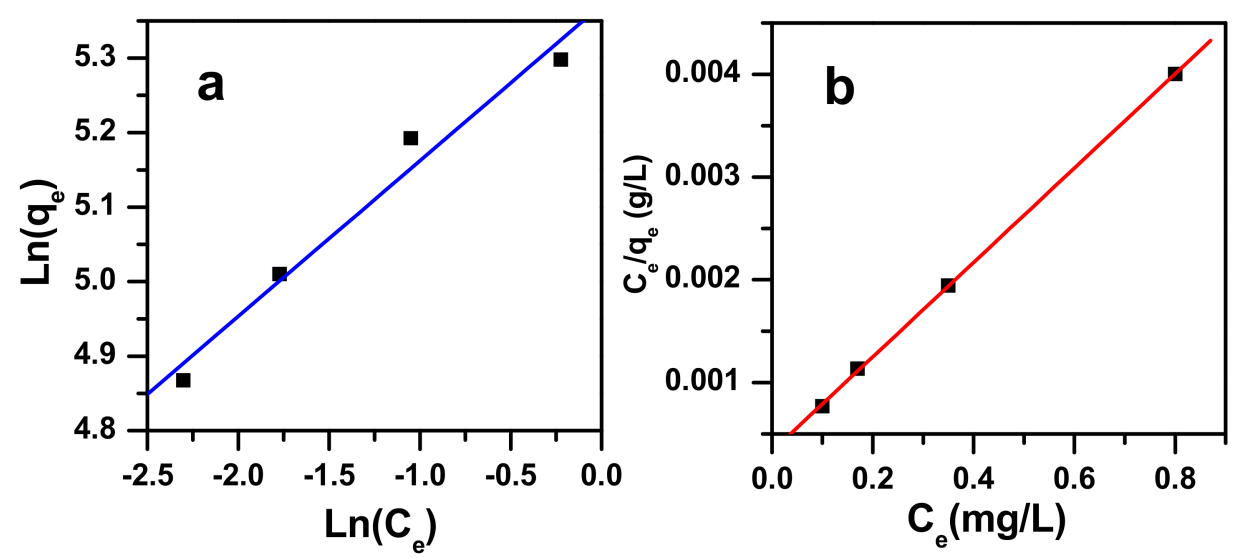

Figure 11. Freundlich (a) and Langmuir (b) isotherms for methylene blue dye adsorption onto zinc molybdate nanocatalyst at $\mathrm{pH}=3$ at room temperature.

Table 2. Isotherm parameters for the adsorption of $\mathrm{MB}$ dye onto zinc molybdate surface at $\mathrm{pH}=3$ in room temperature.

\begin{tabular}{ccccccc}
\hline \multicolumn{3}{c}{ Langmuir } & \multicolumn{4}{c}{ Freundlich } \\
\hline $\mathrm{qm}_{\mathrm{m}}(\mathrm{mg} / \mathrm{g})$ & $\mathrm{K}_{\mathrm{L}}(\mathrm{L} / \mathrm{mg})$ & $R^{2}$ & Range $\mathrm{R}_{\mathrm{L}}$ & $\mathrm{q}_{\mathrm{F}}\left(\mathrm{mg}^{1-1 / \mathrm{n}} / \mathrm{L}^{1 / \mathrm{n}} / \mathrm{g}\right)$ & $1 / \mathrm{n}$ & $R^{2}$ \\
\hline 217.86 & 13.80 & 1 & $0.0003-0.0006$ & 215.10 & 0.21 & 0.97 \\
\hline
\end{tabular}


In this study, comparing the correlation coefficient values $\left(R^{2}\right)$ for Langmuir and Freundlich isotherms, it has been found out that the Langmuir isotherm best fits the adsorption data rather than the Freundlich isotherm. Therefore, adsorption of the MB dye on zinc molybdate forms the adsorbate monolayer, which takes place on homogeneous adsorption sites. The surface area of the zinc molybdate adsorbent is $18.9 \mathrm{~m}^{2} / \mathrm{g}$, and a pore size of $297 \AA$, and hence, this reaches a maximum adsorption capacity value.

\subsubsection{Desorption Isotherm}

The rate of desorption of MB from the catalyst after its adsorption vs time is presented in Figure 12. The results shown that the equilibrium in these conditions was reached after one hour of contact time, leading to $27 \%$ of desorption. These results suggested that both of physisorption and chemisorptions take place in the same time. What was removed from the catalyst was the MB adsorbed by physisorption.

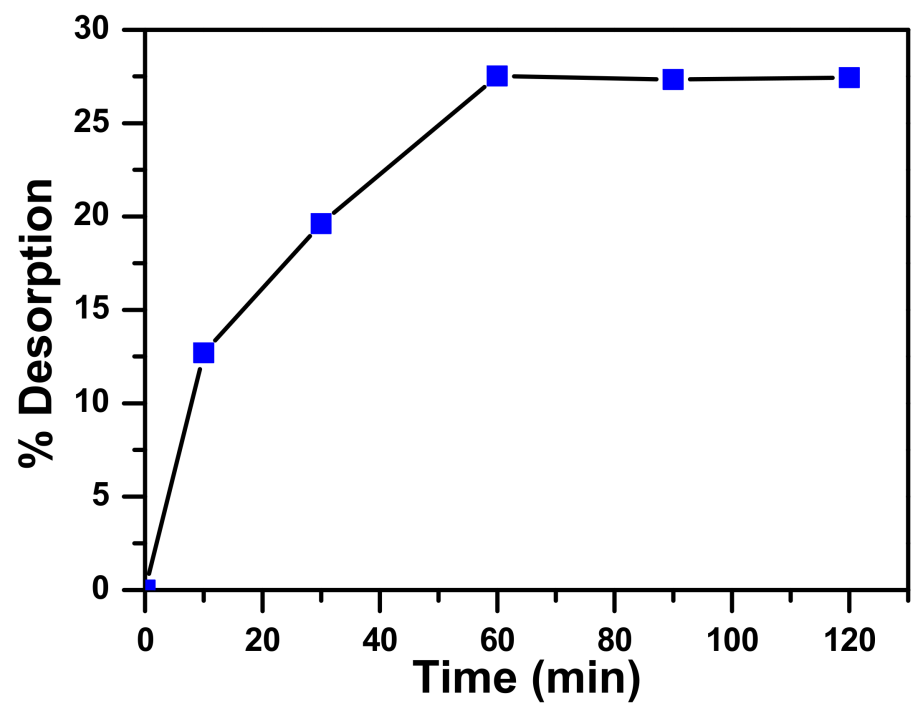

Figure 12. Rate of MB desorption from zinc molybdate after adsorption from MB 130 ppm solution at ambient temperature.

\section{Conclusions}

The synthesized zinc molybdate nanoparticles show high efficiency for two important applications in aqueous solutions, namely the removal of methylene blue and the reduction of 3-NP. Therefore, it can be concluded that the studied zinc molybdate is an essential catalyst as a nominee for the reduction of nitro functional groups in an amino group, and an efficient nanoadsorbent for the removal of methylene blue dye via the adsorption technique.

Author Contributions: Conceptualization, H.O.H. and M.A.; Methodology, H.O.H., and M.A.; Validation, H.O.H., and M.A.; Formal Analysis, H.O.H., M.A., S.R., A.M., and F.A.W.; Investigation, H.O.H., M.A., S.R., A.M., and F.A.W.; Resources, H.O.H., M.A., S.R., A.M., and F.A.W.; Data Curation, H.O.H., M.A., S.R., A.M., and F.A.W.; Writing-Original Draft Preparation, H.O.H., M.A., S.R., A.M., and F.A.W.;Writing-Review \& Editing, H.O.H., and M.A.; Visualization, H.O.H., M.A., S.R., A.M., and F.A.W.; Supervision, H.O.H., and M.A.; Project Administration, H.O.H. and M.A.; Funding Acquisition, H.O.H., M.A., S.R., A.M., and F.A.W.

Funding: This research received no external funding.

Conflicts of Interest: The authors declare no conflict of interest. 


\section{References}

1. Cornu, L.; Jubera, V.; Demourgues, A.; Salek, G.; Gaudon, M. Luminescence properties and pigment properties of A-doped ( $\mathrm{Zn}, \mathrm{Mg}) \mathrm{MoO}_{4}$ triclinic oxides (with $\mathrm{A}=\mathrm{Co}, \mathrm{Ni}, \mathrm{Cu}$ or Mn). Ceram. Int. 2017, 43, 13377-13387. [CrossRef]

2. Wang, D.; Huang, M.; Zhuang, Y.; Jia, H.-1.; Sun, J.; Guan, M. Phase- and Morphology-Controlled Synthesis of Zinc Molybdate for Excellent Photocatalytic Properties. Eur. J. Inorg. Chem. 2017, 42, 4939-4946. [CrossRef]

3. Ramezani, M.; Hosseinpour-Mashkani, S.M.; Sobhani-Nasab, A.; Estarki, H.G. Synthesis, characterization, and morphological control of $\mathrm{ZnMoO}_{4}$ nanostructures through precipitation method and its photocatalyst application. J. Mater. Sci. Mater. Electron. 2015, 26, 7588-7594. [CrossRef]

4. Jiang, Y.-R.; Lee, W.W.; Chen, K.-T.; Wang, M.-C.; Chang, K.-H.; Chen, C.-C. Hydrothermal synthesis of $\beta-Z_{n M o O}$ crystals and their photocatalytic degradation of Victoria Blue R and phenol. J. Taiwan Inst. Chem. Eng. 2014, 45, 207-218. [CrossRef]

5. Lv, L.; Tong, W.; Zhang, Y.; Su, Y.; Wang, X. Metastable monoclinic ZnMoO ${ }_{4}$ : hydrothermal synthesis, optical properties and photocatalytic performance. J. Nanosci. Nanotechnol. 2011, 11, 9506-9512. [CrossRef] [PubMed]

6. Lovisa, L.X.; Oliveira, M.C.; Andres, J.; Gracia, L.; Li, M.S.; Longo, E.; Tranquilin, R.L.; Paskocimas, C.A.; Bomio, M.R.D.; Motta, F.V. Structure, morphology and photoluminescence emissions of $\mathrm{ZnMoO}_{4}$ : $\mathrm{RE}^{3+}$ $=\mathrm{Tb}^{3+}-\mathrm{Tm}^{3+}-\mathrm{X} \mathrm{Eu}^{3+}(\mathrm{x}=1,1.5,2,2.5$ and $3 \mathrm{~mol} \%)$ particles obtained by the sonochemical method. J. Alloys Compd. 2018, 750, 55-70. [CrossRef]

7. Luitel, H.N.; Chand, R.; Watari, T. $\mathrm{ZnMoO}_{4}: \mathrm{Er}^{3+}, \mathrm{Yb}^{3+}$ phosphor with controlled morphology and enhanced upconversion through alkali ions doping. Opt. Mater. 2018, 78, 302-311. [CrossRef]

8. Han, C.L.; Luo, L.; He, J.Q.; Wang, J.X.; Zhang, W. Synthesis and luminescence properties of $\mathrm{ZnMoO}_{4}: \mathrm{Eu}^{3+}$, $\mathrm{M}^{+}\left(\mathrm{M}^{+}=\mathrm{Li}^{+}, \mathrm{Na}^{+}\right.$and $\left.\mathrm{K}^{+}\right)$phosphors. J. Mater. Sci. Mater. Electron. 2017, 28, 4409-4413. [CrossRef]

9. Chengaiah, T.; Jayasankar, C.K.; Pavani, K.; Sasikala, T.; Moorthy, L.R. Preparation and luminescence characterization of $\mathrm{Zn}(1-\mathrm{x}) \mathrm{MoO}_{4}: \mathrm{xDy}^{3+}$ phosphor for white light-emitting diodes. Opt. Commun. 2014, 312, 233-237. [CrossRef]

10. Yu, L.; Nogami, M. The synthesis and photoluminescent properties of one-dimensional $\mathrm{ZnMoO}_{4}: \mathrm{Eu}^{3+}$ nanocrystals. Mater. Lett. 2010, 64, 1644-1646. [CrossRef]

11. Zhang, G.K.; Yu, S.J.; Yang, Y.Q.; Jiang, W.; Zhang, S.M.; Huang, B.B. Synthesis, morphology and phase transition of the zinc molybdates $\mathrm{ZnMoO}_{4} \cdot 0.8 \mathrm{H}_{2} \mathrm{O} / \alpha-\mathrm{ZnMoO}_{4} / \mathrm{ZnMoO}_{4}$ by hydrothermal method. J. Cryst. Growth 2010, 312, 1866-1874. [CrossRef]

12. Zhou, L.Y.; Wei, J.S.; Gong, F.Z.; Huang, J.L.; Yi, L.H. A potential red phosphor $\mathrm{ZnMoO}_{4}: \mathrm{Eu}^{3+}$ for light-emitting diode application. J. Solid State Chem. 2008, 181, 1337-1341. [CrossRef]

13. Ryu, J.H.; Koo, S.M.; Yoon, J.W.; Lim, C.S.; Shim, K.B. Synthesis of nanocrystalline $\mathrm{MMoO}_{4}(\mathrm{M}=\mathrm{Ni}, \mathrm{Zn})$ phosphors via a citrate complex route assisted by microwave irradiation and their photoluminescence. Mater. Lett. 2006, 60, 1702-1705. [CrossRef]

14. Zazhigalov, V.A.; Sachuk, O.V.; Kopachevska, N.S.; Starchevskyy, V.L.; Sawlowicz, Z. Effect of Ultrasonic Treatment on Formation of Nanodimensional Structures in $\mathrm{ZnO}-\mathrm{MoO}_{3}$ System. Theor. Exp. Chem. 2017, 53, 53-59. [CrossRef]

15. Chernyak, D.M.; Danevich, F.A.; Degoda, V.Y.; Dmitruk, I.M.; Ferri, F.; Galashov, E.N.; Giuliani, A.; Ivanov, I.M.; Kobychev, V.V.; Mancuso, M.; et al. Optical, luminescence and thermal properties of radiopure $\mathrm{ZnMoO}_{4}$ crystals used in scintillating bolometers for double beta decay search. Nucl. Instrum. Methods Phys. Res. Sect. A 2013, 729, 856-863. [CrossRef]

16. Beeman, J.W.; Danevich, F.A.; Degoda, V.Y.; Galashov, E.N.; Giuliani, A.; Ivanov, I.M.; Mancuso, M.; Marnieros, S.; Nones, C.; Pessina, G.; et al. An Improved $\mathrm{ZnMoO}_{4}$ Scintillating Bolometer for the Search for Neutrinoless Double Beta Decay of ${ }^{100}$ Mo. Low Temp. Phys. 2012, 167, 1021-1028. [CrossRef]

17. Jeseentharani, V.; Dayalan, A.; Nagaraja, K.S. Co-precipitation synthesis, humidity sensing and photoluminescence properties of nanocrystalline $\mathrm{Co}^{2+}$ substituted zinc(II) molybdate (Zn1-xCoxMoO 4 ; x = 0, 0.3, 0.5, 0.7, 1). Solid State Sci. 2017, 67, 46-58. [CrossRef]

18. Mardare, C.C.; Tanasic, D.; Rathner, A.; Mueller, N.; Hassel, A.W. Growth inhibition of Escherichia coli by zinc molybdate with different crystalline structures. Phys. Status Solidi A 2016, 213, 1471-1478. [CrossRef] 
19. Luitel, H.N.; Chand, R.; Hamajima, H.; Gaihre, Y.R.; Shingae, T.; Yanagita, T.; Watari, T. Highly efficient NIR to NIR upconversion of $\mathrm{ZnMoO}_{4}: \mathrm{Tm}^{3+}, \mathrm{Yb}^{3+}$ phosphors and their application in biological imaging of deep tumors. J. Mater. Chem. B 2016, 4, 6192-6199. [CrossRef]

20. Gao, Y.P.; Huang, K.J.; Zhang, C.X.; Song, S.S.; Wu, X. High-performance symmetric supercapacitor based on flower-like zinc molybdate. J. Alloys Compd. 2018, 731, 1151-1158. [CrossRef]

21. Yoon, Y.-S.; Fujikawa, N.; Ueda, W.; Moro-oka, Y.; Lee, K.-W. Propane oxidation over various metal molybdate catalysts. Catal. Today 1995, 24, 327-333. [CrossRef]

22. Maggiore, R.; Galvagno, S.; Bart, J.C.J.; Giannetto, A.; Crisafulli, C.; Toscano, G. Catalytic oxidation of propene over zinc, cadmium and nickel molybdates. Z. Phys. Chem. 1983, 137, 111-118. [CrossRef]

23. Zazhigalov, V.A.; Sachuk, E.V.; Kopachevskaya, N.S.; Bacherikova, I.V.; Wieczorek-Ciurowa, K.; Shcherbakov, S.N. Mechanochemical Synthesis of Nanodispersed Compounds in the $\mathrm{ZnO}-\mathrm{MoO}_{3}$ System. Theor. Exp. Chem. 2016, 52, 97-103. [CrossRef]

24. Verma, N.; Mari, B.; Singh, K.C.; Jindal, J.; Mollar, M.; Yadav, S. Luminescence properties of ZnMoO $\mathrm{Zn}_{4}: \mathrm{Eu}^{3+}: \mathrm{Y}^{3+}$ materials synthesized by solution combustion synthesis method. AIP Conf. Proc. 2016, 1724, 020130. [CrossRef]

25. Jain, N.; Singh, B.P.; Singh, R.K.; Singh, J.; Singh, R.A. Enhanced photoluminescence behaviour of Eu ${ }^{3+}$ activated $\mathrm{ZnMoO}_{4}$ nanophosphors via $\mathrm{Tb}^{3+}$ co-doping for light emitting diode. J. Lumin. 2017, 188, 504-513. [CrossRef]

26. Lakhlifi, H.; Benchikhi, M.; El Ouatib, R.; Er-Rakho, L.; Guillemet-Fritsch, S.; Durand, B. Synthesis and physicochemical characterization of pigments based on molybdenum <<ZnO-MoO3: Co2+>>. J. Mater. Environ. Sci. 2015, 6, 3465-3469.

27. Espinosa Bosch, M.; Ruiz Sánchez, A.J.; Sánchez Rojas, F.; Bosch Ojeda, C. Determination of paracetamol: Historical evolution. J. Pharm. Biomed. Anal. 2006, 42, 291-321. [CrossRef] [PubMed]

28. Qian, W.C.; Luo, X.P.; Wang, X.; Guo, M.; Li, B. Removal of methylene blue from aqueous solution by modified bamboo hydrochar. Ecotoxicol. Environ. Saf. 2018, 157, 300-306. [CrossRef] [PubMed]

29. Miyah, Y.; Lahrichi, A.; Idrissi, M.; Khalil, A.; Zerrouq, F. Adsorption of methylene blue dye from aqueous solutions onto walnut shells powder: Equilibrium and kinetic studies. Surf. Interfaces 2018, 11, 74-81. [CrossRef]

30. Low, S.K.; Tan, M.C. Dye adsorption characteristic of ultrasound pre-treated pomelo peel. J. Environ. Chem. Eng. 2018, 6, 3502-3509. [CrossRef]

31. Mounia, L.; Belkhiri, L.; Bollinger, J.C.; Bouzaza, A.; Assadi, A.; Tirri, A.; Dahmoune, F.; Madani, K.; Remini, H. Removal of Methylene Blue from aqueous solutions by adsorption on Kaolin: Kinetic and equilibrium studies. Appl. Clay. Sci. 2018, 153, 38-45. [CrossRef]

32. Bentahar, S.; Dbik, A.; El Khomri, M.; El Messaoudi, N.; Lacherai, A. Removal of a cationic dye from aqueous solution by natural clay. Groundw. Sustain. Dev. 2018, 6, 255-262. [CrossRef]

33. Kang, S.; Zhao, Y.; Wang, W.; Zhang, T.; Chen, T.; Yi, H.; Rao, F.; Song, S. Removal of methylene blue from water with montmorillonite nanosheets/chitosan hydrogels as adsorbent. Appl. Surf. Sci. 2018, 448, $203-211$. [CrossRef]

34. Sadeghzadeh-Attar, A. Efficient photocatalytic degradation of methylene blue dye by $\mathrm{SnO}_{2}$ nanotubes synthesized at different calcination temperatures. Sol. Energy Mater. Sol. Cells 2018, 183, 16-24. [CrossRef]

35. Zhang, Y.; Li, G.; Liu, J.; Wang, T.; Wang, X.; Liu, B.; Liu, Y.; Huo, Q.; Chu, Z. Synthesis of hierarchical hollow sodium titanate microspheres and their application for selective removal of organic dyes. J. Colloid Interface Sci. 2018, 528, 109-115. [CrossRef] [PubMed]

36. Oliva, J.; Martinez, A.I.; Oliva, A.I.; Garcia, C.R.; Martinez-Luevanos, C.; Garcia-Lobato, M.; Ochoa-Valiente, M.; Berlanga, A. Flexible graphene composites for removal of methylene blue dye-contaminant from water. Appl. Surf. Sci. 2018, 436, 739-746. [CrossRef]

37. Bayat, M.; Javanbakht, V.; Esmaili, J. Synthesis of zeolite/nickel ferrite/sodium alginate bionanocomposite via a co-precipitation technique for efficient removal of water-soluble methylene blue dye. Int. J. Biol. Macromol. 2018, 116, 607-619. [CrossRef] [PubMed]

38. Kanakaraju, D.; Shahdad, N.R.M.; Lim, Y.C.; Pace, A. Magnetic hybrid $\mathrm{TiO}_{2} / \mathrm{Alg} / \mathrm{FeNPs}$ triads for the efficient removal of methylene blue from water. Sustain. Chem. Pharm. 2018, 8, 50-62. [CrossRef]

39. Oudghiri-Hassani, H. Synthesis, characterization and catalytic performance of iron molybdate $\mathrm{Fe}_{2}\left(\mathrm{MoO}_{4}\right)_{3}$ nanoparticles. Catal. Commun. 2015, 60, 19-22. [CrossRef] 
40. Abboudi, M.; Messali, M.; Kadiri, N.; Ben Ali, A.; Moran, E. Synthesis of CuO, $\mathrm{La}_{2} \mathrm{O}_{3}$, and $\mathrm{La}_{2} \mathrm{CuO}_{4}$ by the Thermal-Decomposition of Oxalates Precursors Using a New Method. Synth. React. Inorg. Met. Org. Nano Met. Chem. 2011, 41, 683-688. [CrossRef]

41. Messali, M.; Al Wadaani, F.; Oudghiri-Hassani, H.; Rakass, S.; Al Amri, S.; Benaissa, M.; Abboudi, M. Preparation, characterization and photocatalytic activity of hexagonal $\mathrm{ZnO}$ nanoparticles. Mater. Lett. 2014, 128, 187-190. [CrossRef]

42. Oudghiri-Hassani, H.; Rakass, S.; Wadaani, F.T.; Al-ghamdi, K.; Omer, A.; Messali, M.; Abboudi, M. Synthesis, characterization and photocatalytic activity of $\alpha-\mathrm{Bi}_{2} \mathrm{O}_{3}$ nanoparticles. J. Taibah Univ. Sci. 2015, 9, 508-512. [CrossRef]

43. Abboudi, M.; Oudghiri-Hassani, H.; Wadaani, F.; Rakass, S.; Al Ghamdi, A.; Messali, M. Enhanced catalytic reduction of para-nitrophenol using $\alpha-\mathrm{MoO}_{3}$ molybdenum oxide nanorods and stacked nanoplates as catalysts prepared from different precursors. J. Taibah Univ. Sci. 2018, 12, 133-137. [CrossRef]

44. Nakamoto, K. Infrared and Raman Spectra of Inorganic and Coordination Compounds Part. B: Applications in Coordination, Organometallic, and Bioinorganic Chemistry, 6th ed.; Wiley: New York, NY, USA, 2009; pp. 152-165. ISBN 978-0-471-74493-1.

45. Ng, K.Y.S.; Zhou, X.; Gulari, E. Spectroscopic characterization of molybdenum oxalate in solution and on alumina. J. Phys. Chem. 1985, 89, 2477-2481. [CrossRef]

46. Ramis, G.; Yi, L.; Busca, G. Ammonia activation over catalysts for the selective catalytic reduction of $\mathrm{NO}_{\mathrm{x}}$ and the selective catalytic oxidation of $\mathrm{NH}_{3}$. An FT-IR study. Catal. Today 1996, 28, 373-380. [CrossRef]

47. Wen, N.; Brooker, M.H. Ammonium Carbonate, Ammonium Bicarbonate, and Ammonium Carbamate Equilibria: A Raman Study. J. Phys. Chem. 1995, 99, 359-368. [CrossRef]

48. Rivenet, M.; Roussel, P.; Abraham, F. One-dimensional inorganic arrangement in the bismuth oxalate hydroxide $\mathrm{Bi}\left(\mathrm{C}_{2} \mathrm{O}_{4}\right) \mathrm{OH}$. J. Solid State Chem. 2008, 181, 2586-2590. [CrossRef]

49. Shaheen, W.M. Thermal behaviour of pure and binary basic nickel carbonate and ammonium molybdate systems. Mater. Lett. 2002, 52, 272-282. [CrossRef]

50. Angermann, A.; Topfer, J. Synthesis of nanocrystalline Mn-Zn ferrite powders through thermolysis of mixed oxalates. Ceram. Int. 2011, 37, 995-1002. [CrossRef]

51. Fagerlund, G. Determination of specific surface by BET method. Mater. Constr. 1973, 6, 239-245. [CrossRef]

52. Barrett, E.P.; Joyner, L.G.; Halenda, P.P. The Determination of Pore Volume and Area Distributions in Porous Substances. I. Computations from Nitrogen Isotherms. J. Am. Chem. Soc. 1951, 73, 373-380.

53. Goyal, A.; Bansal, S.; Singhal, S. Facile reduction of nitrophenols: Comparative catalytic efficiency of $\mathrm{MFe}_{2} \mathrm{O}_{4}$ $(\mathrm{M}=\mathrm{Ni}, \mathrm{Cu}, \mathrm{Zn})$ nano ferrites. Int. J. Hydrog. Energy 2014, 39, 4895-4908. [CrossRef]

54. Hassani, H.O.; Al Wadaani, F.T. Preparation, Characterization and Catalytic Activity of Nickel Molybdate $\left(\mathrm{NiMoO}_{4}\right)$ Nanoparticles. Molecules 2018, 23, 273. [CrossRef] [PubMed]

55. Nandanwar, S.U.; Chakraborty, M. Synthesis of Colloidal $\mathrm{CuO} / \gamma-\mathrm{Al}_{2} \mathrm{O}_{3}$ by Microemulsion and Its Catalytic Reduction of Aromatic Nitro Compounds. Chin. J. Catal. 2012, 33, 1532-1541. [CrossRef]

56. Al-Wadaani, F.; Omer, A.; Abboudi, M.; Hassani, H.O.; Rakass, S.; Messali, M.; Benaissa, M. High Catalytic Efficiency of Nanostructured $\beta-\mathrm{CoMoO}_{4}$ in the Reduction of the Ortho-, Meta- and Para-Nitrophenol Isomers. Molecules 2018, 23, 364. [CrossRef] [PubMed]

57. Xia, J.; He, G.; Zhang, L.; Sun, X.; Wang, X. Hydrogenation of nitrophenols catalyzed by carbon black-supported nickel nanoparticles under mild conditions. Appl. Catal. B Environ. 2016, 180, 408-415. [CrossRef]

58. Holbrook, K.A.; Twist, P.J. Hydrolysis of the Borohydride Ion catalysed by Metal-Boron Alloys. J. Chem. Soc. A Inorg. Phys. Theor. 1971, 890-894. [CrossRef]

59. Mahida, V.P.; Pate, M.P. Removal of some most hazardous cationic dyes using novel poly (NIPAAm/AA/N-allylisatin) nanohydrogel. Arab. J. Chem. 2016, 9, 430-442. [CrossRef] 
60. Du, Q.; Sun, J.; Li, Y.; Yang, X.; Wang, X.; Wang, Z.; Xia, L. Highly enhanced adsorption of congo red onto graphene oxide/chitosan fibers by wet-chemical etching off silica nanoparticles. Chem. Eng. J. 2014, 245, 99-106. [CrossRef]

61. Dawood, S.; Sen, T.K. Removal of anionic dye Congo red from aqueous solution by raw pine and acid-treated pine cone powder as adsorbent: Equilibrium, thermodynamic, kinetics, mechanism and process design. Water Res. 2012, 46, 1933-1946. [CrossRef] [PubMed]

Sample Availability: Samples of the compounds zinc molybdate ( $\alpha$-ZnMoO4) are available from the authors.

(C) 2018 by the authors. Licensee MDPI, Basel, Switzerland. This article is an open access article distributed under the terms and conditions of the Creative Commons Attribution (CC BY) license (http://creativecommons.org/licenses/by/4.0/). 